Mr. Pendred recalled some of the historic vessels and a few of the notable inventions connected with marine propulsion in the early days of steam navigation, he avoided the well-trodden path which leads to the epoch-making ships connected with ocean travel or with fighting fleets, and turned aside to consider the development of ships designed especially for cargo carrying. These he said are "the lesser vessels which do the come-day go-day work of the world; the tramps and freighters slogging their patient way across the Bay, facing typhoons in the China Sea, picking their courses 'twixt Scylla and Charybdis, nosing themselves into little ports looking for cargoes; never certain where next their lawful occasions may take them". By means of curves of tonnage, horse-power, speed, steam pressures and the like, he endeavoured to show how, in these as in all ships, economy has been attained. In 1887 a typical tramp had a displacement of 4,840 tons ; in 1896, 7,075 tons; in 1911, 10,000 tons and in $1928,12,380$ tons ; and during this time the coal consumption per knot per ton dead weight carrying capacity had fallen 40 per cent. To those who would call a halt to invention he said, "not the wills of all the anti-mechanization people in the whole world will check for a fraction of a second the wheel that began to spin a hundred and forty years ago when James Watt produced the rotative steam engine". Further economy in cargo ships must be and will be sought.

\section{The Waitaki Hydro-electric Installation, New Zealand}

The opening on October 26 by Lord Bledisloe, Governor-General of the Dominion of New Zealand, of the hydro-electric power station near Kurow, on the Waitaki River in the South Island, was the occasion of an imposing ceremony attended by the Prime Minister (the Right Hon. G. W. Forbes) and other ministers and public men. It was a noteworthy event in the annals of the country, being the inauguration of the largest installation of water-power so far developed there. The following brief details of the undertaking are extracted from the Wellington Evening Post. The total length of the impounding dam is $1,800 \mathrm{ft}$., with a spillway $1,200 \mathrm{ft}$. long. The structure, which contains half a million tons of concrete, has a maximum height of $120 \mathrm{ft}$. and a base width of $145 \mathrm{ft}$. The power house, $350 \mathrm{ft}$. long, $150 \mathrm{ft}$. wide and $130 \mathrm{ft}$. high, is an integral part of the dam and provides for the reception of five turbo-generators, each of 23,000 horse-power, of which only two, as yet, have been installed. Lord Bledisloe in his address said that electric supply is available to no less than 94 per cent of the total population (a percentage probably not exceeded in any other country in the world) with an average consumption per capita of about 500 units per annum. The total capital invested in electrical supply undertakings in New Zealand is $£ 32,000,000$, of which $£ 28,000,000$ has been expended during the last eleven years. During the same period, Government expenditure has amounted to $£ 10,500,000$. The average cost of eurrent for ordinary domestie purposes is $1 \cdot 31 d$. per unit as compared with $1 \cdot 30 d$. in Great Britain and $1 \cdot 39 d$. in the United States. Lord Bledisloe urged a fuller recognition of the complementary possibilities of user on the part of urban and rural consumers, and the extent to which one could assist the other.

\section{Mangarevan Expedition of the Bernice P. Bishop Museum}

ON October 28, Bernice P. Bishop Museum welcomed the natural history party of the Mangarevan Expedition returning to Honolulu aboard the specially designed sampan Islander from six months' field work in south-eastern Polynesia. The Mangarevan Expedition was organised for the explora. tion of little-known islands and atolls in extreme south-eastern Polynesia. Of the thirty-one islands and many atolls and reefs on which the party landed, particular attention was given to Anaa, Napuka, Tatakoto, Hao, Mangareva, Timoe, Pitcairn, Henderson, Oeno, Rapa, Raivavae, Rurutu and Rimatara. Surveys supplementing those made by Bishop Museum in previous years were conducted at Tubuai, Tahiti, Raiatea, Huahine and Borabora. To gain access to atolls and cliff-bound volcanic islands, a ship of high power and shallow draught was designed, and to permit the party to divide its forces for particular kinds of work, a transfer ship and power launches were provided. The expedition was made possible by generous grants from the Rockefeller Foundation and from institutions and individuals in Hawaii. Regarding the expedition, Prof. Herbert E. Gregory, director of Bernice P. Bishop Museum, remarks: "Under the experienced leadership of Dr. D. Montague Cooke, ably supported by Captain William Anderson of the Islander, the program of the expedition was carried out with marked success. The collections, which include some 15,000 sheets of plants, 40,000 insects, 160,000 land shells, and representative series of other animals, is sufficient to give a fairly complete picture of the land fauna and flora of the southeastern Pacific, and to indicate the relation of the oceanic islands to South America. The expedition practically completed the general survey of the ethnology and natural history of Polynesia which has been the chief interest of the Museum since 1920."

\section{Third International Locust Conference}

IT is not unusual for proceedings of international scientific congresses to be published some months, or even years later, but this cannot be said with regard to the Third International Locust Conference held in London in September (see NATure, 134, 484, Sept. 29, 1934). The volume of its proceedings was issued by H.M. Stationery Office two months after the Conference. It is a very compact publication which contains in its 184 pages a mass of first-hand and thoroughly up-to-date information on the locust problem. The official part of the proceedings occupies only a relatively small portion of the volume, while the bulk of it consists of papers presented by various experts. The papers deal with all sides of the locust problem in a very brief and concise manner, discussing the most important points to be investigated 
and the methods of doing it. The set of resolutions adopted by the Conference, and printed in English and French, presents a mass of very detailed and valuable recommendations for future research. Although the Conference was concerned only with the locust problem in Africa and western Asia, the resolutions should be of great assistance in all countries where the locust problem is studied, because many of the recommendations with regard to the organisation and methods of research are applicable to any country. In view of the recent disastrous developments in the locust situation in South and North America, Australia and China, the work of the London Conference will undoubtedly have a worldwide appeal. It has laid a firm foundation for the international scientific attack on the locust problem and the main task of the next Conference, to be held in 1936 in Cairo, will be to extend the existing anti-locust front to all the countries suffering from these pests.

\section{Imperial Agricultural Research}

THE fourth annual report of the Executive Council of the Imperial Agricultural Bureaux, recently issued, continues the story of the smooth and successful working of an Imperially controlled and financed organisation (Imperial Agricultural Bureaux. Fourth Annual Report of the Executive Council, 1932-1933. Pp. 23. (London : H.M. Stationery Office, 1934.) 1s. net). The period under review marks the end of the two years' term of office of Mr. F. L. McDougall, the representative of Australia, as chairman of the Council ; and for the next two years Sir Charles $J$. Howell Thomas, the United Kingdom representative, has been elected chairman, with Mr. Nevill L. Wright, New Zealand, as vice-chairman. The most important event in the year was the inquiry made into the work and organisation of the Bureaux, in common with that of other inter-Imperial organisations, by the Imperial Committee on Economic Consultation and Co-operation, appointed as a result of one of the resolutions of the Ottawa Conference. That committee of inquiry not only recommended the continuance of the work but also accepted the organisation as a general model for inter-Imperial organisations and proposed that additional duties be placed on the Council. The main functions of the Bureaux are the collecting, sifting and distributing of information on research in eight branches of agricultural science; and the nine abstract journals already started have now become well established. In addition, a number of reviews with bibliographies on special subjects have been published, and the issue from Weybridge of the "Index Veterinarius"-a compete index of all papers and publications on veterinary science-has been sanctioned.

\section{Physical Investigation of 'Immaterial' Bodies}

THERE has recently been published by the Dr. William Bernard Johnston Foundation for Psychological Research, Reno, Nevada, a pamphlet by R. A. Watters entitled "The Intra-Atomic Quantity". Mr. Watters describes a series of experiments in which grasshoppers, frogs and mice were killed in a Wilson expansion chamber, a cloud produced at the moment of death, and the resulting 'tracks' photographed. It is alleged that these photographs reveal forms corresponding in shape to the dead bodies, and it is claimed that this result demonstrates the existence of an "intra-atomic Quantity" which is an "immaterial body" and an "exact counterpart of the physical body to which it belongs". It is further claimed that when the subjects of the experiments were removed from the Wilson chamber and gave any signs of life, the photographs never showed. anything unexpected; but that when the photographs showed 'intra-atomic' tracks, the subjects were unquestionably dead. Unfortunately, the few photographs reproduced in the bulletin before us reveal the alleged markings only to the eye of faith; for the rest, the essential experimental details are almost wholly wanting. If Mr. Watters wishes his work to receive attention, he should publish a more adequate and a more fully illustrated report.

\section{Calculating Machine for Simultaneous Equations}

The calculating machine for the solution of differential equations constructed by Dr. V. Bush, of the Massachusetts Institute of Technology, has attracted a great deal of attention, and a similar machine is being built in Great Britain by Prof. D. R. Hartree of Manchester. Dr. Bush has now, in collaboration with Dr. J. B. Wilbur, constructed another machine, the purpose of which is to give the solution of a number of simultaneous algebraic equations of the first degree. A larger model, containing nearly 1,000 pulleys and more than 500 feet of steel tape, has been designed, but is not yet constructed. This will deal with ten variables connected by ten equations, and will be of great use in the solution of problems such as the determination of stresses in buildings and the adjustment of triangular networks in surveying, which, treated by ordinary methods, require long and tedious calculations.

\section{Toads Save Sugar Crop}

Biological control seldom extends to the importation of Amphibia, but great success has followed the establishment of the large toad Bufo marinus in Puerto Rico. From two lots of this species brought to Puerto Rico from Barbadoes and Jamaica, millions of descendants have sprung, and the food of this host has consisted largely of the May-beetle (Science Service, Washington, D.C.). The sugar crop, which is the staple product of the island, was threatened by great numbers of the 'white-grubs' of May. beetles, which swarmed everywhere in the soil, devouring the roots of the cane and of other plants as well, so that the planters were reduced to picking the grubs by hand. The introduction of the toad has reduced the May-beetles to scarcity, and the Porto Rican sugar crop has been freed from its worst enemy.

\section{The 200-inch Mirror}

According to a message from its New York correspondent which appeared in the Times of December 